\title{
Commentary: New SPIDER graft spins a large web
}

\author{
J. Hunter Mehaffey, MD, MSc, and Robert B. Hawkins, MD, MSc
}

From the Division of Thoracic and Cardiovascular Surgery, University of Virginia, Charlottesville, Va. Disclosures: Authors have nothing to disclose with regard to commercial support.

Received for publication Nov 20, 2018; accepted for publication Nov 20, 2018; available ahead of print Dec 28, 2018.

Address for reprints: J. Hunter Mehaffey, MD, MSc, Department of Thoracic and Cardiovascular Surgery, University of Virginia, PO Box 800679, Charlottesville, VA 22908-0709 (E-mail: jhm9t@ virginia.edu).

J Thorac Cardiovasc Surg 2019;158:702-3

$0022-5223 / \$ 36.00$

Copyright (c) 2018 by The American Association for Thoracic Surgery

https://doi.org/10.1016/j.jtcvs.2018.11.069

In this issue of the Journal, Wipper and colleagues ${ }^{1}$ have presented the results of a well-designed feasibility study evaluating the SPIDER graft as follow-up to their original study $^{2}$ from earlier this year in the European Journal of Vascular and Endovascular Surgery. The current study nicely presents the results of using an updated version of the SPIDER graft, along with a larger sample size, in their porcine model. ${ }^{2}$ In addition, they report modifications in implantation technique, as well as tissue perfusion data, to support their findings. Wipper and colleagues ${ }^{1}$ compare results of animals that received the new SPIDER graft with those of a control open aortic repair group as well as with those of another SPIDER group that underwent lumbar artery reimplantation.

Aside from death, neurologic and spinal cord injury remain the most devastating complications encountered during these procedures. Advances in thoracoabdominal aneurysm repair have been incremental, with adjuncts such as lumbar drainage, arterial reimplantation, and hybrid procedures with staged thoracic endovascular aortic repair and open abdominal repair leading to reduced spinal cord injury. ${ }^{3}$ The current SPIDER system integrates the staged repair into a single abdominal operation. The avoidance of a thoracotomy and extracorporeal circulatory support has the potential to reduce kidney and lung complications. The lack of time for spinal adaptation, however, may prove a crucial shortcoming that meticulous reimplantation may not be able to overcome.

In this study, the open aortic repair group was used for comparison with the SPIDER graft groups. One advantage of an open approach is the option to reimplant portions of the segmental spinal blood supply; in this study, however, the vessels were oversewn in the open repair group. This raises the question of whether Wipper and colleagues ${ }^{1}$ provide a "fair" comparison between groups when assessing spinal perfusion. There might have been

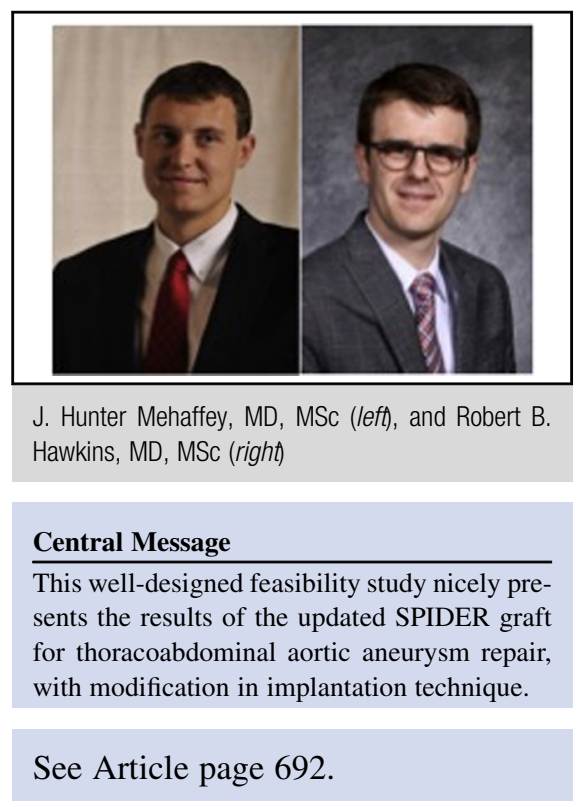

less of a difference had the vessels been reimplanted in the open repair group. Furthermore, spinal drainage is commonly used to decrease the risk of injury during open and endovascular thoracoabdominal aneurysm repair. Hayatsu ${ }^{4}$ and colleagues have used spinal drainage in a porcine model previously; however, the study of Wipper and colleagues ${ }^{1}$ omitted this widely used adjuvant. Finally, it must be considered that the anatomy of the porcine spinal blood supply is markedly different from that of humans. The segmental thoracic and lumbar arteries are relatively small and often originate as a single branch from the aorta. ${ }^{5}$ It will be important to see these results borne out when translated to first in human studies.

This is an exciting time in translational research as we bridge the gap between open surgery and endovascular repairs. As technology catches up with the imagination of cardiac surgeons, there will be many options for less-invasive approaches to surgical treatment of thoracoabdominal aneurysms. The SPIDER graft represents an important incremental advance, and we congratulate Wipper and colleagues $^{1}$ on this work.

\section{References}

1. Wipper S, Kölbel T, Sandhu HK, Manzoni D, Duprée A, Estrera AL, et al. Impact of hybrid thoracoabdominal aortic repair on visceral and spinal cord perfusion: the new and improved SPIDER-graft. J Thorac Cardiovasc Surg. 2019;158:692-701. 2. Debus ES, Kölbel T, Wipper S. The SPIDER graft: a new hybrid device for thoraco-abdominal aortic repair. Eur J Vasc Endovasc Surg. 2019;57:588. 
3. Hawkins RB, Mehaffey JH, Narahari AK, Jain A, Ghanta RK, Kron IL, et al. Improved outcomes and value in staged hybrid extent II thoracoabdominal aortic aneurysm repair. J Vasc Surg. 2017;66:1357-63.

4. Hayatsu Y, Kawamoto S, Matsunaga T, Haga Y, Saiki Y. Real-time monitoring of spinal cord blood flow with a novel sensor mounted on a cerebrospinal fluid drainage catheter in an animal model. J Thorac Cardiovasc Surg. 2014;148: 1726-31.

5. Strauch JT, Lauten A, Zhang N, Wahlers T, Griepp RB. Anatomy of spinal cord blood supply in the pig. Ann Thorac Surg. 2007;83 2130-4.

Access to The Journal of Thoracic and Cardiovascular Surgery Online is reserved for print subscribers!

Full-text access to The Journal of Thoracic and Cardiovascular Surgery Online is available for all print subscribers. To activate your individual online subscription, please visit The Journal of Thoracic and Cardiovascular Surgery Online, point your browser to http://www.mosby.com/jtcvs, follow the prompts to activate your online access, and follow the instructions. To activate your account, you will need your subscriber account number, which you can find on your mailing label (note: the number of digits in your subscriber account number varies from 6 to 10 ). See the example below in which the subscriber account number has been circled:

\section{Sample mailing label}

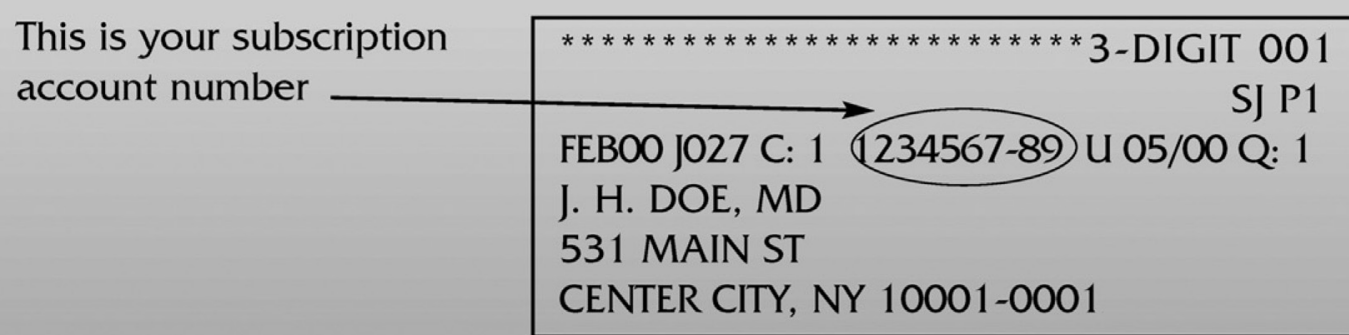

Personal subscriptions to The Journal of Thoracic and Cardiovascular Surgery Online are for individual use only and may not be transferred. Use of The Journal of Thoracic and Cardiovascular Surgery Online is subject to agreement to the terms and conditions as indicated online. 